\title{
Training the future social teachers to the work with children with special needs in Ukraine
}

\author{
Olga Khyzhna ${ }^{1}$ \\ Karina Shafranska ${ }^{2}$
}

\section{Abstract}

This article deals with the problem of the social and pedagogical training of the students who are studying at the Pedagogical University and proposes new ways of their solution. It is important today that the main task of the pedagogical science is to make system of the socialist and pedagogical training of future social teacher to the work with children with special needs in Ukraine.

\section{Keywords}

the social work, the scientific activity, the professional ability, the socialist and pedagogical training.

The current period of dynamic changes in social and cultural development of Ukraine proposes new requirements for higher education in Ukraine, including priority is the formation of the modern generation, able to learn throughout life, to create and develop the values of civil society. Modern social worker - is primarily a specialist in social engineering and technology. As a sociologist and educator, he has deeply understand the legal, moral, psychological regulatives of human activity and should be able and willing to come to their aid, to help efficiently and graciously.

The concept of «social work» means an expression of human attitude human to human. It came into being in biblical times as charity, religious duty of the believer as a system of humanitarian services to those who needs of help. But only in the last century, this work is recognized as a profession that requires special training. Social work differs from philanthropy, charity, patronage of art and similar kinds of activities oriented not only to assist people in solving daily problems (employment, welfare, health, relationships with other members of society), but the development, necessary coping skills and self-organization skills.

World experience certifying the effectiveness of assistance provided by is not isolated loners, powerful professional associations that support the government and the general public. In the West, gradually formed the view that assistance to people who get lost or objective reasons cannot enter into it (the disabled, the old, single, unemployed, poor and other social outsiders), is an indicator of high culture and civilized society.

Contemporary developing of Ukraine is proceeding in forming of threats as ecological and demographic situation, reduction of production, increasing of poverty, illness and criminality, change of moral standards of society and corruption.

In Ukraine social work is located in formative stage. The domestic model of preparation of social workers should be built on the basis of historical experience, be scientifically and economically justified, legally backed, methodically perfect, creative, based on the best foreign models, consider the

1 Olga Khyzhna, Professor, Doctor of Pedagogics, The Drahomanov National Pedagogical University, Ukraine, e-mail: khyzhna@gmail.com

2 Karina Shafranska, PhD, Warsaw University of Life Sciences, Warsaw, Poland, e-mail: karina.szafranska@sonica.com.pl 
next and distant prospects of Ukrainian society. In the opinion 0. Bermus, "It is in the current situation, characterized by intensification of contacts, mass migration, active processes in society, education should be reconsidered, primarily as a tool for new historical and social communities" [5, p.366-367].

Social work in society is a presentation of essence of social politics of the country, which embraces different aspects of life. This set the educational process on the human values, open the creative potential of the future socialist teachers, predetermines transform the system of developing the future socialist teacher according to international educational standards and creates necessity of improving the work of the pedagogical educational establishments about developing the training the future socialists' teachers to the work with children with special needs.

Importance of this problem is conditioned not only by increasing the number of children, which have physical psychological defects but short standards of material security of families with these children, their social and moral exposure.

The goal of this article is specification of the possible ways of modernizing the system of training the social sector workers in Ukraine and reasoning of social problem in training the future social teachers to the work with children with special needs; argue the impossible ways of modernization such training.

Education is one of the important social system, which the functional role was chanced within century. Before the Age of Enlightenment, the main goal of education was development of social elite, but the mass education was only to religious background. In the Age of Enlightenment educational system was changed to an instrument of improving of qualification and development of civil loyalty. However, the content of education was classical and the knowledge was mostly theoretical. The methodology was unchangeable, the main principles were based by J.-A. Komensky.

The classic articles which are devoted to the role of education in society are written by American analytics D. Bell, J. Neysbit, M. Kastels. These researchers characterized a new society as a "society of knowledge" [7] and megatrend of the world evolution determined the combination of technological achievements and quality of life. Inspiration to scientific researches becomes the key point due to accessibility of education to people and adjunction them to scientific work and direction to searching of high technologies and innovations.

Philosophical and pedagogical researches which are directed on the whole search of development of the educational system are actually important. It is a result not only of actuality of demand of the development of educational system, but with necessity of training and upbringing of youth in informational civilization, growth of creative component of system of education.

The term "social work" determines human relation of people. It comes from the bible age as charity, and system of human service. Nevertheless, in previous century this work was defined as profession that needs special training. Social work differs from philanthropy, charity, patronage not only by helping people in everyday solving problems, but to development of ability overcoming difficulties, skills of self-work. The world experience shows the effectiveness of help which was given not by one self, but professional service, which are helped by state and public. Subsequently on the West there was an opinion about the help to people which are in trouble (old, solitary, out of work, poor disabled people), it was an indicator of good culture and civilization of society.

Development of social work started at the beginning of industrial society because of XIX century characterized with growth of cities, intensification of exploitation, social differentiation, growth of crime, unemployment, lack of spirituality. Gradually due to social reformates and progressive public in Great Britain, Netherlands, the USA, Switzerland, Japan and other developed countries a ramified system of theoretical knowledge and the law, ethic, didactics bases of social work was formed. In this progress it based on biology, medicine, statistic, sociology, pedagogy, anthropology, psychology, economics, law and other sciences, on self-experience, informatization achievements, new technologies. This gives an opportunity to resolve the main problem: studying, diagnose and treatment of social problems.

For example, the structure of training the social teachers in Great Britain is designated by Central Council for Education and Training in Social Work) which was founded in 1983. This Council creates the national educational standards, licenses the departments of social work, define the competence of candidates of social work. This competence consists of demonstration of knowledge, skills and appreciation of values of social work. Usually in traditional educational establishments the two years programs are suggested to students. We want to point out, that Ukraine does not have such organizations, but it is 
considerable to create it in system of high education.

In contradiction to Ukrainian system of training the future social teachers the main goal in social training in Britain is not only theoretical education, but practical skills of social work. Much attention is on the forming professional ethic and self-development of students.

In Ukraine social work is keep on developing. The Ukrainian model of social work should base on historical experience, to be scientifically and economically argued, law proved, be in high methodological level, also be creative, to be based on the best foreign experience, to consider with the perspectives of Ukrainian society.

Considering with specific of multinational society in our country, different problems, that are a result of geopolitical situation in solving social problems it is considerable to solve the of ethic, national problems, that can support to the forming of social environment; it gives an opportunity to emphasize on such principles as ethical determinism of social influence, which provides a base on actions which can be comprehended by representatives of other nationalities and are equal to the traditions and habits of this society, be considerable with national and psychological specifics that was founded in influence of national consciousness and social activity, which provides considering with moral and consciousness of representatives of other ethnic society. The next principle is principle of work in specific of national mentality and national ideal, which demands a complex of social activity according with national traditions; principle of individual approach to the representatives of every nation, which considering not only national specific of person, but also individual characteristics which are peculiar to every person and groups.

Contemporary social teacher - is firstly a professional in social engineer and technologies sphere. As a social and teacher, he should be a professional in law, moral, psychological issues, he must be able to qualified and good help. For realization of main functions of social work, he must a) be competent, knowledge in psychology, pedagogy, physiology, economy, statistics b) to be master in the new information about contemporary political, economic, law processes in society and to appreciate them c) to cooperate with different clients d) to be professional sensitivity, to challenge sympathy, trust, to keep client's secrecy, be delicate e) can be operative in considering different tasks in extreme situations.

Thus, the main goal of social teacher is to help the client to find himself, his place in life, to get orientation in social conditions and relations.

Most of specialists from different countries are dealing with problem of determine the term "social work" - in interpretation as awareness, that providing the guarantee social help to person, to comply the requests and benefit to poor people - is not social work. Social work has to be professional. Social work is teaching the clients to be active in solving their problems that is the main function of social help as professional activity. Every professional action must be connected with pedagogy; it should set the goals and development tasks. They considering with principles of upbringing, based on its content, using methods of activity, consolidation, strengthening of positive experience, self-experience.

Pedagogical goals can be realized only in case of complex cooperation of system social work which foresees the unity of all types of help: psychological, material, law, medical. Success can be in result of cooperation social and pedagogical factors of the social services. According to the practice, successful solution of developmental goal is a result of respect and trustful relations between and his client. It is the essence of pedagogical social help. In social work the main role belongs to upbringing, which help person to survive, to adapt in changeable world, to realize personal opportunities, to cooperate with people. The process of development - is going on process of forming consciousness, behavior, ideals, habits, feelings, character, moral features, all these main bases for social work building.

That's why social work is a pedagogical work in social sphere with person, which has serious problems. These problems not only homelessness, alcoholism, addiction, disability, old age, but also those, which are connected with forming the features which need pedagogical correction (high self-esteem, laziness, cruelty, aggressiveness, jealousy).

Social cultural rehabilitation we consider as specific way of realization, with special activities which focused on arising adaptive opportunities of disabled child.

Important aspect is consideration of it not as an influence, but cooperation with a family on a partner basement, complex and system of strains.

Social teacher should take into consideration the all factors, which influence on the client: a family, 
the neighbors, relatives. According to thought of Polish scientist B. Gurnicka and L. Walechko, the effective solving of different professional tasks is depend on the professional essential features level as tolerance, empathy, sensitiveness, absence of eternal conflicts [6].

Today, the discipline "Social pedagogy" is very important. We consider social pedagogy as a branch which studies the essence of social development with subject of basement and development of person in different micro societies. Professional training of the future social teachers on innovative activity is forming in high educational establishments. This period, when the future social teacher is sensitive to different problem of education, is considerable to the development of motivational value attitude to pedagogical situations. According to analyzes for most practical pedagogical teachers the low level of innovative behavior is typical, readiness for such practice, that is a result of traditional education in the university.

Contemporary society of educational innovations is changed by social-economic situation, which occurs with transition from industrial to postindustrial, informational society and demand not "improving" of educational system but modernization. In spite of widespread using of innovative terminology in scientific and methodological articles and researches, analyze of application the educational innovations represent the local cases of them in practice without proved awareness and theoretical-methodological provision of the structural components of educational system.

Effective application of innovations in educational process depends on teachers. Teacher should aware the value of educative quality of pedagogical cooperation, innovations on functional role stage: change of monological technology of education on dialogical and polylogical technology of pedagogical communication, cooperation with students in searching and knowledge activity; substitution the role of "translator" of knowledge as a main resource of learning information on multi role action - partner, tutor, communicator, colleague, facilitator (intellectual and psychological help) on the base of help, cooperation and creativeness. These named functional-role transformations in educational society demand change the technology in teaching in dialogical context [8].

Unfortunately, the most set educational tradition, pedagogical stereotype is application by teacher the role of notice, opponent with fixing attention on defects, which mostly makes the students feel shy, brake their professional and personal development. One way to overcome this is to give the student opportunity to mistake, attitude to the mistake as to cognition and initiate the search of ways of solving this problem by students. Given a mark of the knowledge as analyze and self-analyze of the results of studying hasn't get the development multifunctional: using the mark as an instrument for knowledge and upbringing of students motivate-emotional sphere, forming the skills of professional reflex, necessity in self-development. Orientation not on the mark, but on the skills of searching the information, analyzing, transforming, draw conclusions gives the nature character of intellectual-creative searching and is the main criteria of quality professional training. Innovative behavior of the future social teacher - is a complex of personal appearance, which shows eternal parts of "I" (outlook, personal features), which are directed on change the components of the contemporary training of the future social teacher.

In world practice the change of "cultural utility" to "cultural worth" is observed. In concept of personal oriented conception, a child with birth of acquired defects regardless of able and profitable for society is surveyed as the object of social help, care and need to found conditions for maximal selfactualization, realization the all present opportunities of integration to society. Integration of children with special needs in public society - it is the most goal of disabled children's rehabilitation, which have many specific problems and the main problem - is the personal children development.

Within the forming readiness of the student to work with children with special needs should consider such aspects:

1. Social teacher's sensitivity to personal psychology-pedagogy experience.

It is necessary to know the ways and variants of conditions, factors, local and serious situations about other (psychological) positions. Versatile approach to the social-pedagogical experience, qualified analyze and selective attitude to the old methods in combination with new psychological knowledge provide productive synthesis of psychology-pedagogical knowledge and the new level of professional competence.

2. Reflection is defined in using analyze of psychology-pedagogical activity and its results, which comprehends appreciation of professional level, prognoses of professional progress, organization of 
cognition and self-diagnose, keeping the back contact (with children, colleges, administration)

3. Forming the oriented-searching position of the teacher according to aspects of "another" (adopted) social-pedagogy experience. Forming of such position provides special approach to appreciation of opportunities of realization the ways of pedagogical cooperation, defines the conditions of their use.

4. Forming the integrated approach to analyzing the problem social-pedagogical situations. The specific of such situations in educational process deals with a great number of participants with their functions, ways of cooperation and interests. So, the attempts of solving the problem situation based only on the local features can be failed.

5. Forming the skills of solving the tasks with colleges. This provides an opportunity of comparison their opinions with colleges, parents, searching the effective solutions not only by defending self-think, but common generation.

Consequently, realization of these aspects provides a system in training the future social teachers to the work with children with special need in period of education in high educational establishments and on the stage of after diploma training and in the process of medical therapy of the professionalpedagogical skill. It is considerable to select the following perspective approaches of cooperative development between social work and social pedagogy in Ukraine:

- Creation the organization with deals with training the students to social-pedagogical activity, which the main goal is the creation the national standards, license, of the departments and institutes of social work;

- Intensification of the forming the professional sensitivity and personal development;

- Creation of the cooperation with social services in the process of training the future social teachers to the work with children with special need.

So, readiness the future social teachers to the work with children with special need consider the presence of motivation-emotional attitude to the profession, skills in methodology of reaching the socialpedagogical goals, facility to be creative and sensitive. We want to point out that social-pedagogical activity is a way of optimization of the process of socialization the children with special need and performs the function of social culture adaptation, prevention, exclusion, social cultural rehabilitation and play the main role in the work with such families.

\section{References}

1. Training future specialty - in practice / / http://www.kmu.gov.ua

2. Shakhray V.M Technologies of Social Work. Study Guide. - K.: Center for Educational Literature, 2006. - Page 464.

3. Aktualni problemy sotsialno-pedahohichnoi roboty (modulnyi kurs dystantsiinoho navchannia) / A. I. Kapska, O. V. Bezpalko, R. Kh. Vainola; Zahalna redaktsiia A. I. Kapskoi. - K., 2002. - 164s.

4. Bolonskyi protses u faktakh i dokumentakh/Uporiadnyky Stepko M. F., Boliubash Ya. Ia., Hrubiianko V. V., Babin I. I.- K.- Ternopil: Vyd-vo TDPU im. V. Hnatiuka, 2003. - 52 s.

5. Bermus A.G. Modernizatsiya obrazovaniya: filosofiya, politika, kultura: Nauchnaya monografiya / A. G. Bermus - M.: «Kanon+» R00I «Reabilitatsiya», 2008.-384 s.

6. Górnicka B., Waleczko Ł. Terapeutyczne aspekty organizacji czasu wolnego dziecka niepełnosprawnego przez rodziców, [w:] Rodzicielstwo w sytuacji dezorganizacji rodziny. Możliwości wspomagania rodziców, red. J.Brągiel, B. Górnicka, Opole 2004, Wyd. UO, s.284.

7. Kastels M. Informatsionnaya epokha: ekonomika, obshchestvo i kultura. - M.: GU VShE, 2000.

8. Khyzhna 0, Lendel-Sarkevich A. Peace Education as Arts Education: In Search of New Strategies// Philosophy and Cosmology, Volume 21 The Academic Journal ISSN 2518-1866 (Online), ISSN 23073705 (Print). 